\title{
Characterizing the Presence and Sensitivity of the P2X7 Receptor in Different Compartments of the Gut
}

\author{
Nathalia Enes de Campos ${ }^{a}$ b Camila Marques-da-Silva ${ }^{a} \quad$ Gladys Corrêa $^{a}$ \\ Morgana Teixeira Lima Castelo-Branco ${ }^{c}$ Heitor Siffert Pereira de Souza ${ }^{b}$ \\ Robson Coutinho-Silva ${ }^{a}$ \\ a Programa de Imunobiologia, Instituto de Biofísica Carlos Chagas Filho, bepartamento de Clinica Médica, \\ Hospital Universitário Clementino Fraga Filho, e ${ }^{\complement}$ Programa de Glicobiologia, Instituto de Ciências Biomédicas, \\ Universidade Federal do Rio de Janeiro, Rio de Janeiro, Brasil
}

\section{Key Words}

P2X7 receptor modulation - Mesenteric lymph nodes •

Peritoneum · Adenosine triphosphate

\begin{abstract}
Purinergic signaling has been established as an important feature of inflammation and homeostasis. The expression of a number of $\mathrm{P} 2$ receptor subtypes in the gut has been reported. In this study, using a well-known permeabilization method that is assessed by flow cytometry, we show that lymphocytes and macrophages from the mesenteric lymph nodes (MLN) and the peritoneal cavity exhibit different sensitivities to extracellular ATP. Compared with the macrophages, the lymphocytes are more sensitive to ATP in the MLN compartment, whereas in the peritoneal cavity the macrophages are more sensitive to ATP than the lymphocytes. In addition, we have shown that the epithelial cells from the small bowel are more resistant to the ATP effects than the cells from the colon. These cells, however, become susceptible after exposure to IFN- $\gamma$. Furthermore, by examining parameters such as $\mathrm{pH}$ manipulation, the exposure to divalent cations and the $P 2 X 7$ antagonist Brilliant Blue $G$, and
\end{abstract}

the use of cells from $\mathrm{P} 2 \mathrm{X7}^{-/-}$mice, we have shown that the P2X7 receptors are the ATP-activated receptors responsible for the permeabilization phenomenon. In addition, using Western blot analysis, we have demonstrated the changes in the $\mathrm{P} 2 \mathrm{X} 7$ receptor expression in immune cells isolated from different sites in the gut and in the gut-associated lymphoid tissues. Our findings suggest the existence of the site-specific modulation of $\mathrm{P} 2 \mathrm{X} 7$ receptors on epithelial and immune cells, and we define purinergic signaling as a new regulatory element in the control of inflammation and cell fate in the gut and in the gut-associated lymphoid tissues.

Copyright $\odot 2012$ S. Karger AG, Basel

\section{Introduction}

The $\mathrm{P} 2 \mathrm{X} 7$ receptors are members of the ATP-activated $\mathrm{P} 2 \mathrm{X}$ receptor family and constitute a cation ion channel that is permeable to $\mathrm{K}^{+}, \mathrm{Na}^{+}$and $\mathrm{Ca}^{2+}$. Depending on the

N.E. de Campos and C. Marques-da-Silva contributed equally to this work.

\section{KARGER \\ Fax +4161306 1234 \\ E-Mail karger@karger.ch}

www.karger.com
(C) 2012 S. Karger AG, Basel

$1662-811 X / 12 / 0046-0529 \$ 38.00 / 0$

Accessible online at:

www.karger.com/jin
Prof. Robson Coutinho-Silva

Instituto de Biofísica Carlos Chagas Filho - UFRJ

Edifício do Centro de Ciências da Saúde, Bloco G, Av. Carlos Chagas Filho, 373

Cidade Universitária, Ilha do Fundão, Rio de Janeiro, RJ 21941-902 (Brazil)

Tel. +55212562 6565, E-Mail rcsilva@ biof.ufrj.br 
cell type, the activation of the $\mathrm{P} 2 \mathrm{X} 7$ receptor by extracellular ATP (ATPe) results in the opening of additional pores that are permeable to hydrophilic solutes with molecular weights below $900 \mathrm{Da}$ including some fluorescent dyes [1]. The P2X7 receptors function as danger sensors in immune cells and have been implicated in proliferation, cell death, cell differentiation and the production and release of proinflammatory cytokines such as IL-1 $\beta$, IL-6, IL-18 and TNF- $\alpha$ [reviewed in 2]. In macrophages, the activation of the $\mathrm{P} 2 \mathrm{X} 7$ receptors is associated with the release of MHC-II-containing exosomes [3], the release of cathepsins [4] and the elimination of intracellular pathogens [5].

The concentration of ATP that elicits P2X7 receptor activation is estimated to be approximately $1 \mathrm{mM}$, a level that is rarely achieved under physiological conditions. However, ATPe concentrations can markedly increase following tissue injury, which includes inflammatory conditions, trauma and ischemia, and in response to pharmacological stimulations [6, 7]. In mice, the P2X7 receptors are also activated by physiological concentrations of NAD [8]. In addition, other inflammatory mediators and bacterial products such as IFN- $\gamma$ [9-11], LPS, TNF- $\alpha$ [12] and prostaglandins [13] are capable of modulating P2X7 receptors in different cells.

The epithelial barrier of the intestinal mucosa is essential for physiological homeostasis and represents one of the first lines of defense against pathogens and exogenous antigens. The integrity of the epithelial barrier and the normal intestinal functions depend on the maintenance of a dynamic equilibrium in cell numbers, cell types and degrees of differentiation. In this sense, apoptosis constitutes a physiological phenomenon that is expected to affect the highly differentiated postmitotic enterocytes as a critical mechanism for cell renewal. The P2X7 receptors have also been detected in the gut epithelia and their expression has been associated with cell death [14]. In addition, ATP is released by epithelial cells $[15,16]$ including intestinal epithelial cells [17]. It is possible, therefore, that under pathological conditions ATPe may be functioning as a signaling molecule to trigger the release of proinflammatory cytokines, to induce apoptosis and to eliminate intracellular bacteria $[2,5,18,19]$.

As shown by Nihei et al. [20] in 2000 and Korpi-Steiner et al. [21] in 2008, the functional presence of the P2X7 receptors is confirmed by the use of flow cytometry. In these studies, blood monocytes were used to describe a method for quantitatively analyzing the presence of the $\mathrm{P} 2 \mathrm{X} 7$ receptor. Taking into consideration that the $\mathrm{P} 2 \mathrm{X} 7$ receptors in the gastrointestinal tract have not been in- vestigated fully, we used the cell sensitivity to ATP as assessed by flow cytometry to characterize the P2X7 receptors in the gut-associated mononuclear cells and in the epithelium from different intestinal sites.

\section{Materials and Methods}

\section{Reagents}

The reagents were obtained from the following sources: phenylmethylsulfonyl fluoride, trypsin inhibitor, leupeptin, antipain, chymostatin, pepstatin, deoxycholate, LPS from Escherichia coli, ethidium bromide (EB), ATP, Brilliant Blue G (BBG) and Triton X-100 were from Sigma-Aldrich (St. Louis, Mo., USA). Hepes and EDTA were from Merck (Darmstadt, Germany). The bicinchoninic acid protein assay was from Pierce (Rockford, Ill., USA). The polyclonal rabbit anti-P2X7 receptor antibodies and the peptide controls were from Alomone (Jerusalem, Israel). The ECL Plus chemiluminescent detection system was from GE Healthcare (Chalfont St. Giles, UK). The $\mathrm{H}_{2}$ DCFDA was from Calbiochem (USA), and the IL-1 $\beta$ ELISA kit and mouse IFN- $\gamma$ were obtained from Peprotech (Rocky Hill, N.J., USA).

\section{Animals}

The breeding, maintenance and euthanasia of the animals used in this study followed the principles of good laboratory animal care and experimentation and complied with the regulations of the Carlos Chagas Filho Biophysics Institute. All the protocols were approved by the local animal ethics committee (IBCCF 039). Adult BALB/c or C57BL/6 wild-type and C57BL/6 P2X7- ${ }^{-1-}$ mice of both sexes were euthanized by asphyxiation using an increasing concentration of $\mathrm{CO}_{2}$, and death was confirmed by cervical dislocation. The peritoneal wash, the mesenteric lymph nodes (MLN), the axillary lymph nodes (ALN), the Peyer's patches (PP), the small bowel, the colon and the lamina propria of the small intestine were removed.

\section{Epithelial Cell Isolation}

In brief, the small bowel and the colon were harvested and flushed twice with phosphate-buffered saline (PBS). The gut was opened longitudinally and cut into $0.5-\mathrm{cm}$ pieces. The colonic and small bowel pieces were incubated (separately) in PBS for $10 \mathrm{~min}$ at $37^{\circ} \mathrm{C}$ and were placed in Hank's balanced salt solution (HBSS) for $2 \times 15$ min periods at $37^{\circ} \mathrm{C}$. The intestinal pieces were incubated with HBSS containing 10\% FCS, $0.625 \mathrm{mM}$ Hepes, $0.05 \mathrm{mM}$ EGTA and $2.5 \%$ penicillin/streptomycin for $15 \mathrm{~min}$ at $37^{\circ} \mathrm{C}$ under constant agitation. The resulting epithelial cells were washed twice with HBSS. To ensure the purity of the isolated epithelial cells, the nonspecific binding sites were blocked for $45 \mathrm{~min}$ using $10 \%$ horse serum, washed and incubated for $1 \mathrm{~h}$ with an FITCconjugated antibody against cytokeratin.

\section{Peritoneal Wash}

After euthanasia, sterile PBS $(8 \mathrm{ml}, \mathrm{pH}$ 7.2) was injected into the peritoneal cavity, which was gently massaged. The fluid was recovered and was transferred to an ice-cooled sterile tube. The cells were centrifuged at $250 \mathrm{~g}$ for $10 \mathrm{~min}$ at $4^{\circ} \mathrm{C}$, the pellet was resuspended in RPMI 1640 medium containing 10\% FCS and $2.5 \%$ penicillin/streptomycin and kept at $4^{\circ}$ or $37^{\circ} \mathrm{C}$ until use. 


\section{$M L N, P P$ and $A L N$ Cell Isolation}

The lymph nodes, PPs and ALNs were removed macroscopically and macerated in RPMI 1640 medium, and the cells were further purified on a Ficoll-Hypaque gradient (Amersham Biosciences) to obtain lymphocytes and macrophages. The cells were maintained in RPMI 1640 containing 10\% FCS and 2.5\% penicillin/streptomycin until use.

\section{IFN- $\gamma$ Treatment}

Following isolation, the cells were treated with $2 \mathrm{ng} / \mathrm{ml}$ murine recombinant IFN- $\gamma$ (Perotech, Rocky Hill, N.J., USA) for $24 \mathrm{~h}$ in RPMI 1640 containing 10\% FCS and $2.5 \%$ penicillin/streptomycin at $37^{\circ} \mathrm{C}$. The cells were gently washed with PBS before the experiments were performed.

\section{Permeabilization Assay}

To assess the ATPe-induced membrane permeabilization, the membrane-impermeable DNA-staining fluorescent dye EB (2.5 $\mu \mathrm{M})$ was used, and the incubation temperature throughout the experiment was maintained at $37^{\circ} \mathrm{C}$. The cells $\left(2 \times 10^{5} /\right.$ sample $)$ obtained from the MLN were maintained for $5 \mathrm{~min}$ in PBS at $\mathrm{pH}$ 6.0 or 7.4 (with or without $\mathrm{Zn}^{2+}, \mathrm{Cu}^{2+}$ or $\mathrm{Cd}^{2+}$ at crescent concentrations) and were treated or not treated with ATP at crescent concentrations for an additional $10 \mathrm{~min}$. During the last $5 \mathrm{~min}$ of the incubation, EB was added to the cells, and the samples were immediately analyzed using a FACScalibur (Becton \& Dickinson, San Jose, Calif., USA) flow cytometer. The specific permeabilization value was calculated following the subtraction of the baseline values for the basal permeabilization of the cells (cells incubated with EB only).

\section{Western Blot}

The tissue was homogenized in 7 vol of ice-cold lysis solution Hepes (25 mM at pH 7.4) containing 0.1 mM EDTA, 0.25\% deoxycholate, $2.5 \%$ Triton X-100 and $0.01 \mathrm{mg} \cdot \mathrm{ml}^{-1}$ of each of the following protease inhibitors: phenylmethylsulfonyl fluoride, trypsin inhibitor, leupeptin, antipain, chymostatin, and pepstatin, and the homogenate was centrifuged at $3,000 \mathrm{~g}$. The protein concentration of the homogenate was determined using a protein assay kit (BioAgency).

The lysate was heated to $98^{\circ} \mathrm{C}$ for $5 \mathrm{~min}$ in a sample buffer (Sigma-Aldrich) and $80 \mu \mathrm{g}$ of total protein was added to each lane. The proteins were separated by SDS-PAGE using $10 \%$ gel and electroblotted onto an Immobilon-P (PVDF) membrane (Millipore), and the nonspecific binding sites were blocked by incubating the membrane in 5\% fat-free milk and $0.2 \%$ Tween 20 in TBS for $2 \mathrm{~h}$ at room temperature. The membrane was incubated overnight at $4^{\circ} \mathrm{C}$ for $2 \mathrm{~h}$ at room temperature with the polyclonal anti-P2X7 receptor antibody (dilution: 1:1,000) or with the respective antibody after preabsorption with its control peptide (negative control). The goat anti-rabbit HRP-conjugated antibody (eBioscience) was used as a secondary antibody at a dilution of 1:1,000. The immunoreactive bands were visualized using the chemiluminescent detection system ECL Plus (GE Healthcare).

\section{Phenotypic Analysis}

The PP and MLN cells were washed twice with PBS, blocked for 45 min with $10 \%$ horse serum, washed again and incubated for $1 \mathrm{~h}$ with FITC-conjugated anti-Mac-1(CD11b) antibody and PEconjugated anti-CD3 antibody. The stained cells were permeabi- lized or left unpermeabilized as described above. For immunofluorescent staining, the cells were analyzed by flow cytometry using a FACSCalibur cytometer.

\section{Immunohistochemical Analysis of the Intestines}

To analyze the tissue expression and the distribution of the $\mathrm{P} 2 \mathrm{X} 7$ receptor in the small bowel and in the colon we utilized an indirect immunoperoxidase technique. The paraffin sections $(3 \mu \mathrm{m})$ were first deparaffinized, rehydrated using distilled water and, for antigen retrieval, the sections were incubated at a high temperature in $0.01 \mathrm{M}$ sodium citrate buffer ( $\mathrm{pH}$ 6.0) in a steamer for $30 \mathrm{~min}$. The slides were immersed in hydrogen peroxide for $10 \mathrm{~min}$ to block the endogenous peroxidase activity. After rinsing in PBS containing 0.5\% Tween 20 for $10 \mathrm{~min}$, the tissue sections were incubated with nonimmune serum for $30 \mathrm{~min}$ and subsequently incubated with the anti-P2X7 receptor mouse monoclonal antibody (Alomone Labs, Israel) in a humidified chamber overnight. After the incubation, the slides were rinsed 3 times and incubated with biotinylated anti-rabbit antibody (Vector Labs, Inc., Burlingame, Calif., USA). For each sample, two sections were incubated with PBS alone or with biotinylated antibody to serve as negative controls. After rinsing in PBS for 10 $\mathrm{min}$, the tissue sections were incubated for $30 \mathrm{~min}$ with a streptavidin-peroxidase conjugate (Zymed Laboratories, Inc., San Francisco, Calif., USA). After an additional rinse, the tissue sections were developed using a solution containing hydrogen peroxide and diaminobenzidine, dehydrated and mounted in a histological mounting medium.

\section{Indirect Immunofluorescence Staining and Confocal Laser Microscopy}

After isolation, the cells were seeded onto slides at a density of $1 \times 10^{6}$ cells $/ \mathrm{ml}$ using a cytospin centrifuge. The cells were fixed, permeabilized, and incubated for $2 \mathrm{~h}$ at room temperature in a blocking buffer (2.5\% bovine serum albumin, $2.0 \%$ skimmed milk, and $8.0 \%$ fetal bovine serum) with shaking. The slides were rinsed once with PBS and $0.05 \%$ Tween 20 and then incubated with the primary antibodies diluted in the blocking buffer. The cells were incubated with anti-P2X7 rabbit antibody (Alomone Labs) and anti-CD11b-FITC mouse antibody (eBioscience) for $1 \mathrm{~h}$ at room temperature. Following the incubation, the slides were rinsed 3 times and incubated with DyLight 549-conjugated anti-rabbit IgG (Vector Labs) for $60 \mathrm{~min}$ at room temperature. A slide from each sample was incubated with PBS alone or with a secondary antibody to serve as a negative control. The slides were air-dried, fixed for $5 \mathrm{~min}$ in a $1 \%$ paraformaldehyde solution and mounted in an antifading medium containing $4^{\prime}, 6-$ diamidino-2-phenylindole (DAPI) (Vector Labs). The expression and localization of the proteins were observed using a Leica TCS-SP5 AOBS confocal laser scanning microscope (Leica, Heidelberg, Germany) and representative images of each sample were captured.

\section{ROS Production}

The cells from the peritoneal wash and the MLN were counted and adjusted to contain the same number of macrophages in each sample. The samples were incubated with $\mathrm{H}_{2}$ DCFDA in HBSS for $30 \mathrm{~min}$ at $37^{\circ} \mathrm{C}$, washed twice with PBS, incubated or not incubated for $15 \mathrm{~min}$ with $1 \mathrm{mM} \mathrm{ATP}$ at $37^{\circ} \mathrm{C}$, and the fluorescence intensity was analyzed using flow cytometry. 
Table 1. Comparisons between the peritoneal and MLN cells for ATP-mediated permeabilization

\begin{tabular}{llrr}
\hline & $\begin{array}{l}\text { Maximum response } \\
\text { \% permeabilized cells }\end{array}$ & $\mathrm{EC}_{50}, \mu \mathrm{M}$ & ATP \\
\hline MLN lymphocytes & $41 \pm 10(\mathrm{n}=10)$ & $27.68^{\#}$ & $500 \mu \mathrm{M}$ \\
Peritoneal lymphocytes & $64 \pm 22(\mathrm{n}=6)$ & $240.90^{\# \#}$ & $5 \mathrm{mM}$ \\
MLN macrophages & $44 \pm 10(\mathrm{n}=10)$ & $79.30^{* * *}$ & $5 \mathrm{mM}$ \\
Peritoneal macrophages & $49 \pm 10(\mathrm{n}=6)$ & $112.12^{*}$ & $5 \mathrm{mM}$ \\
\hline
\end{tabular}

Summary of data from figure 1 which show the values for the maximum number of permeabilized cells, the $\mathrm{EC}_{50}$ and the concentration of ATP used to obtain the maximum number of permeabilized cells. ${ }^{*} \mathrm{p}<0.005$ (MLN macrophages vs. peritoneal macrophages); ${ }^{* * *} \mathrm{p}<0.001$ (MLN lymphocytes vs. peritoneal lymphocytes); ${ }^{\#} \mathrm{p}<0.01$ (MLN lymphocytes vs. MLN macrophages); ${ }^{\#} \mathrm{p}<0.01$ (peritoneal lymphocytes vs. peritoneal macrophages).

\section{$I L-1 \beta$ Secretion}

The cells from the peritoneal wash and the MLN were counted and the concentration was adjusted to contain the same number of macrophages in each sample. They were then incubated with $10 \mathrm{ng} / \mathrm{ml} \mathrm{LPS} \mathrm{for} 4 \mathrm{~h}$ at $37^{\circ} \mathrm{C}$ in HBSS and exposed to $1 \mathrm{mM} \mathrm{ATP}$ for $4 \mathrm{~h}$ at $37^{\circ} \mathrm{C}$. The supernatant was collected and the IL-1 $\beta$ secretion was measured using the manufacturer's protocol.

\section{Statistical Analyses}

The flow cytometry data were analyzed using the WinMDI program (Multiple Document Interface Flow Cytometry Application, V2.8; Scripps Research Institute, La Jolla, Calif., USA). At least 10,000 cells were analyzed for each sample. An unpaired Student $t$ test was used for the statistical evaluation.

\section{Results}

\section{Lymphocytes and Macrophages Display Differential}

\section{$P 2 X 7$ Activity in the MLN and the Peritoneum}

The MLN were removed and processed, and the lymphocytes and macrophages were isolated by density gradient centrifugation using Ficoll-Hypaque and subjected to the permeabilization assay. We observed that both cell types were permeable to EB after treatment with low concentrations of ATPe (fig. 1a). These data showed that the mesenteric cells were more sensitive to ATP than the peritoneal cells. Additionally, we observed that the lymphocytes and macrophages obtained by the peritoneal wash were sensitive to different concentrations of ATP (fig. 1b) and that the macrophages were more sensitive to ATP than the lymphocytes. When we compared the
$\mathrm{EC}_{50}$ of the peritoneal and MLN cells, it was clear that the MLN cells exhibited a higher sensitivity to ATP (table 1).

\section{Divalent Cations and $p H$ Indicates a Role for the} P2X7 Receptor in the ATP-Induced Permeabilization

We used divalent cations to evaluate which $\mathrm{P} 2 \mathrm{X}$ receptors were responding to ATPe in the mesenteric cells. It is well known that copper, zinc and cadmium inhibit P2X7 receptors, and we observed that in the presence of cations the mesenteric lymphocytes and macrophages became less permeable in the presence of ATPe compared with the untreated cells (fig. 2).

In addition, we observed that the permeabilization levels were reduced in the acidic saline (PBS at $\mathrm{pH}$ 6.0) compared with the saline at $\mathrm{pH} 7.4$ (fig. 3a). We also observed that in the presence of a P2X7 antagonist (BBG), the ATP-induced permeabilization of the MLN lymphocytes and macrophages was almost completely reversed, suggesting that the $\mathrm{P} 2 \mathrm{X} 7$ receptor is responsible for the ATP-induced effects (fig. 3b).

Knockout Mice Studies Reveal that the P2X7 Receptor Is Responsible for the ATP-Induced Permeabilization of Mesenteric Cells

To confirm that the permeabilization phenomenon was mediated through the $\mathrm{P} 2 \mathrm{X} 7$ receptor, we isolated lymphocytes and macrophages from the MLN of $\mathrm{P} 2 \mathrm{X}^{-/-}$mice and their wild-type littermates. We did not observe ATP-induced permeabilization in the macrophages or lymphocytes from the $\mathrm{P} 2 \mathrm{X}^{-/-}$mice, whereas ATP did result in the permeabilization of the cells from the wild-type animals (fig. 4a). In addition, we observed that the MLN cells from the C57BL/6 mice were more resistant to the ATP-inducing permeabilization effect (fig. 4a) than the MLN cells from the BALB/c mice (fig. 1a, b). Western blot analysis has shown that in C57BL/6 mice, the MLN cells express lower levels of the $\mathrm{P} 2 \mathrm{X} 7$ receptor than the MLN cells from the BALB/C mice (fig. 4b). These findings were expected because it is known that C57/B16 mice carry a P451L mutation that causes the loss of the P2X7 function, which makes it difficult to compare the results from these two strains of mice. When we compared the expression of the P2X7 receptors in the peritoneal cells, the MLN and the ALN from the $\mathrm{BALB} / \mathrm{c}$ mice, we observed a higher expression of the P2X7 receptor in the MLN cells (fig. 5). In addition, when comparing the ATP-induced permeabilization phenomenon in the macrophages (stained with CD11b antibody) and lymphocytes (stained with CD3 

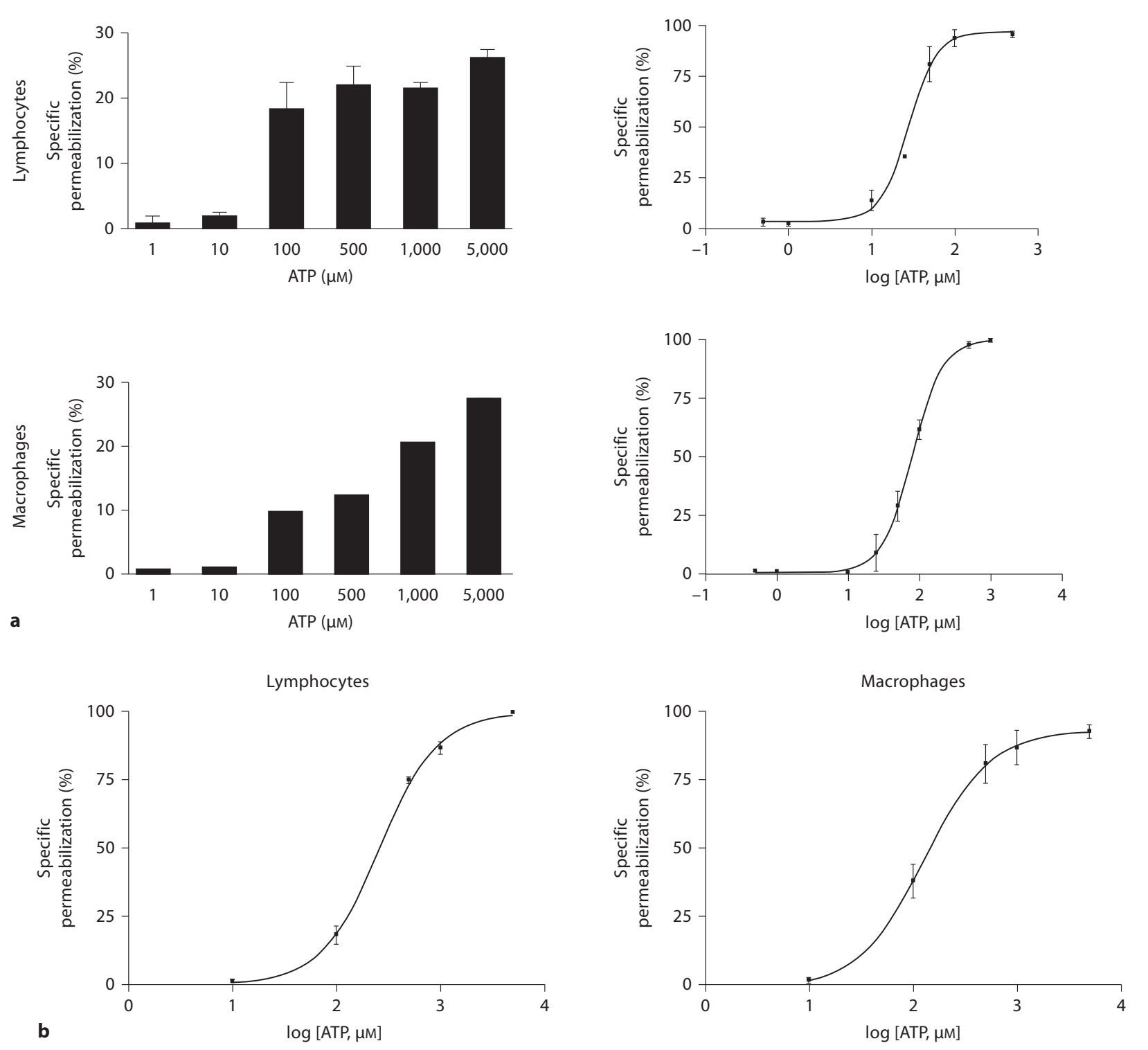

Fig. 1. MLN and peritoneal cells were permeabilized at different ATP concentrations. Mononuclear cells from MLN (a) or the peritoneal cavity (b) were removed and adjusted to $2 \times 10^{5}$ cells/sample. Cells were incubated with increasing concentrations of ATP

for $10 \mathrm{~min}$ at $37^{\circ} \mathrm{C}$. During the last 5 min of incubation $\mathrm{EB}$ was added and samples analyzed by flow cytometry. a MLN cells, individual experiments performed in triplicate, $\mathrm{n}=15$. $\mathbf{b}$ Peritoneal cells, individual experiments performed in triplicate, $\mathrm{n}=7$.

antibody) from the MLN and the PP, we observed that the PP cells were less sensitive to ATP than the MLN cells (fig. 6a, b) even at higher concentrations of ATP (5 mM). The higher level of P2X7 receptor expression in the MLN and peritoneal cells in comparison with the PP was confirmed by confocal images (fig. 6c) and Western blot analysis (data not shown).

Epithelial Cells from the Colon, but Not from the Small Bowel, Are Sensitive to ATP-Induced Permeabilization

The epithelial cells were isolated from the small bowel and colonic tissues and the purity of the cells was confirmed by cytokeratin staining (fig. 7a). After isolation, the intestinal epithelial cells were evaluated for their sen- 


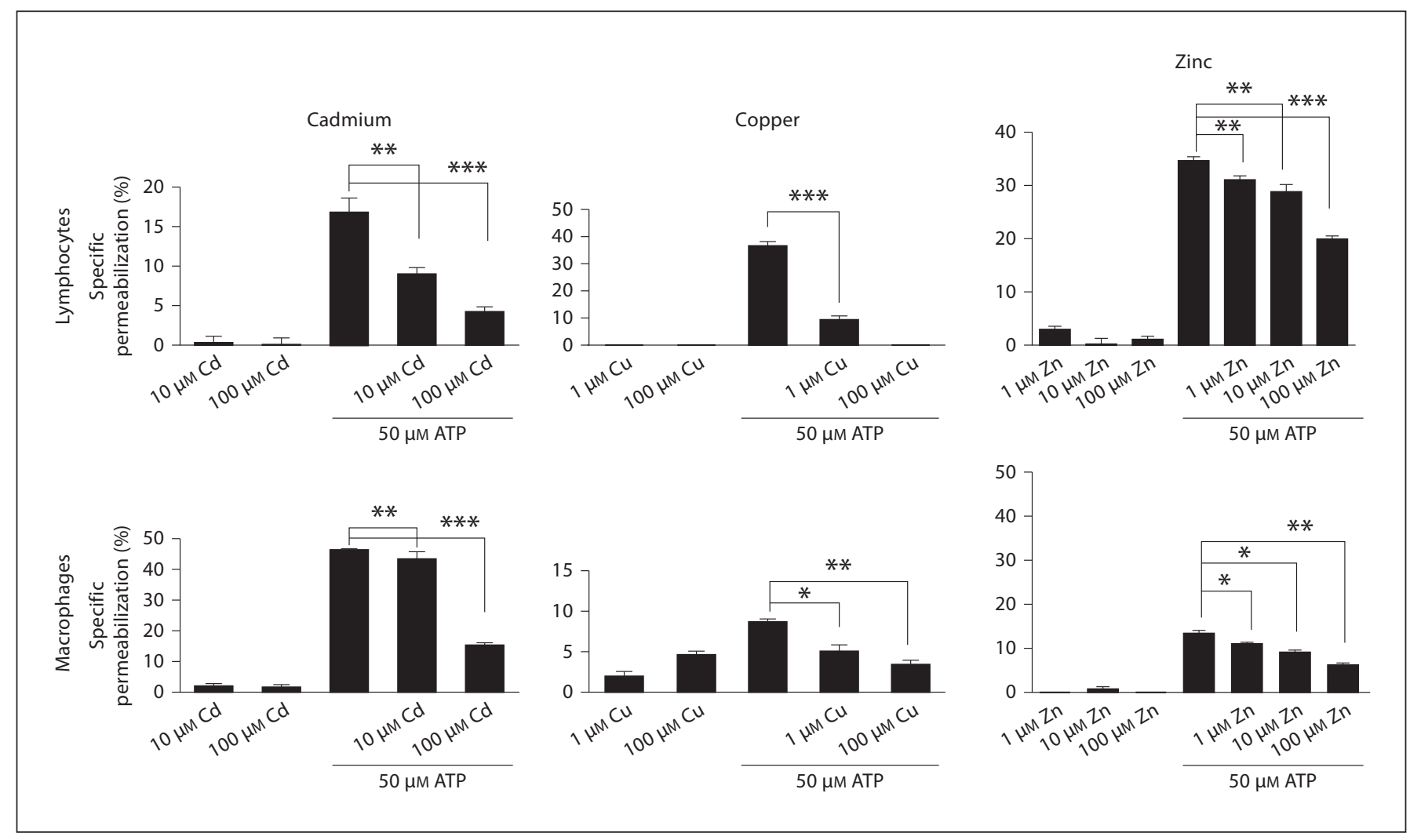

Fig. 2. Divalent cations reduce ATP-induced permeabilization of MLN mononuclear cells. Cells obtained from MLN were removed and adjusted to $2 \times 10^{5}$ cells/sample. Cells were preincubated with copper, cadmium or zinc for $5 \mathrm{~min}$ and $50 \mu \mathrm{M}$ ATP for 10 min at $37^{\circ} \mathrm{C}$. During the last 5 min of incubation EB was added and samples analyzed by flow cytometry. Data are representative of at least 3 individual experiments performed in triplicate. ${ }^{*} \mathrm{p}<$ $0.05,{ }^{* *} \mathrm{p}<0.001,{ }^{* * *} \mathrm{p}<0.0001$. sitivity to ATP. We observed that the epithelial cells from the small bowel were strongly resistant to the ATP-inducing permeabilization effect, whereas the colonic cells were clearly more sensitive to ATP and they exhibited higher levels of permeabilization even at a lower ATP concentration $(1 \mathrm{mM})$. Nevertheless, after pretreatment with IFN- $\gamma$ the small bowel epithelial cells became sensitive to ATP (fig. 7b). The modulation of the P2X7 receptors following the IFN- $\gamma$ treatment was confirmed using Western blot analysis (fig. 7c) and confocal immunofluorescence. The confocal microscopic analysis of the cytospin preparations of freshly isolated cells showed that the $\mathrm{P} 2 \mathrm{X} 7$ receptor is expressed at low levels among the epithelial cells under normal conditions, particularly in the small bowel. However, the expression of P2X7 increased markedly after the treatment with IFN- $\gamma$ (fig. $7 \mathrm{~d}$ ). The P2X7 receptor expression was detected in situ in the small bowel and in the colon of normal mice. Few labeled cells were detected within the epithelial layer, especially in the colon. The labeled cells within the intestinal lamina propria were predominantly mononuclear cells (fig. 7e).

\section{Cells from the MLN Produce More Inflammatory} Mediators than Peritoneal Cells in Response to ATP

The cells from the MLN and the peritoneum produced ROS in response to ATP, and higher levels of ROS were observed in the MLN cells compared with the peritoneal cells (fig. 8a). In contrast, using cells from the P2X7 knockout mice, neither the MLN cells nor the peritoneal cells produced ROS in response to $1 \mathrm{mM} \mathrm{ATP}$ (fig. 8b). An interesting feature of the inflammatory response to ATP is the production and release of IL-1 $\beta$ when the macrophages are preexposed to LPS. The peritoneal and MLN cells released IL- $1 \beta$ in response to ATP, and the IL- $1 \beta$ levels were higher in the MLN cells (fig. 8c). 


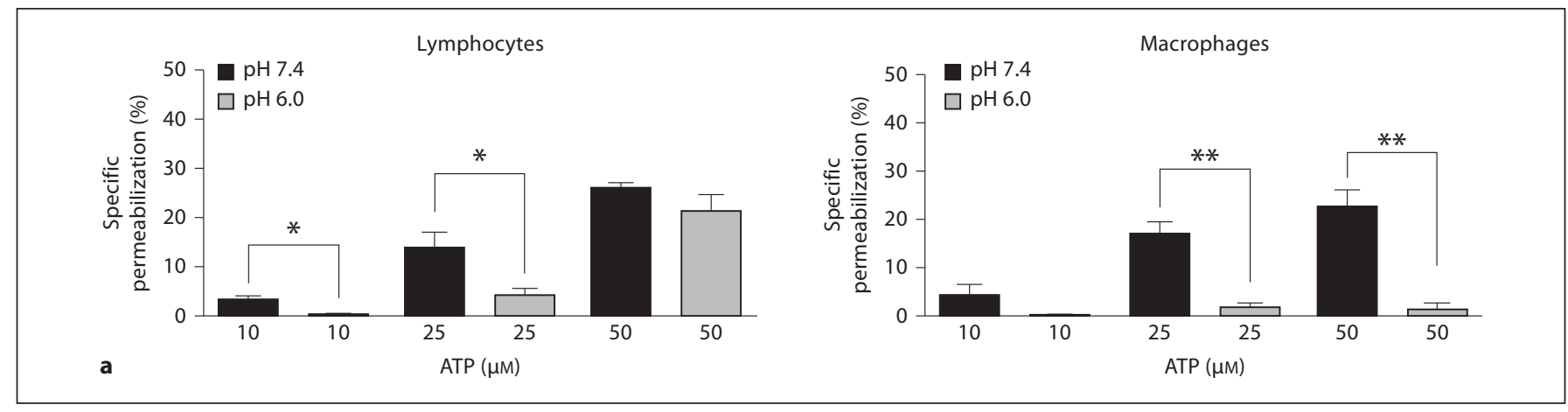

Fig. 3. $\mathrm{pH}$-dependent ATP-induced permeabilization of MLN mononuclear cells. Cells obtained from MLN were removed and adjusted to $2 \times 10^{5}$ cells/sample. Cells were preincubated with PBS pH 7.4 or 6.0 (a) or $18 \mu \mathrm{M} \mathrm{BBG}$ (b) for 5 min and treated with 10,25 or $50 \mu \mathrm{M}$ ATP for $10 \mathrm{~min}$ at $37^{\circ} \mathrm{C}$. During the last $5 \mathrm{~min}$ of incubation EB was added and samples analyzed by flow cytometry. Data are representative of 6 individual experiments performed in triplicate. ${ }^{*} \mathrm{p}<0.05,{ }^{* *} \mathrm{p}<0.001,{ }^{* * *} \mathrm{p}<0.0001$.
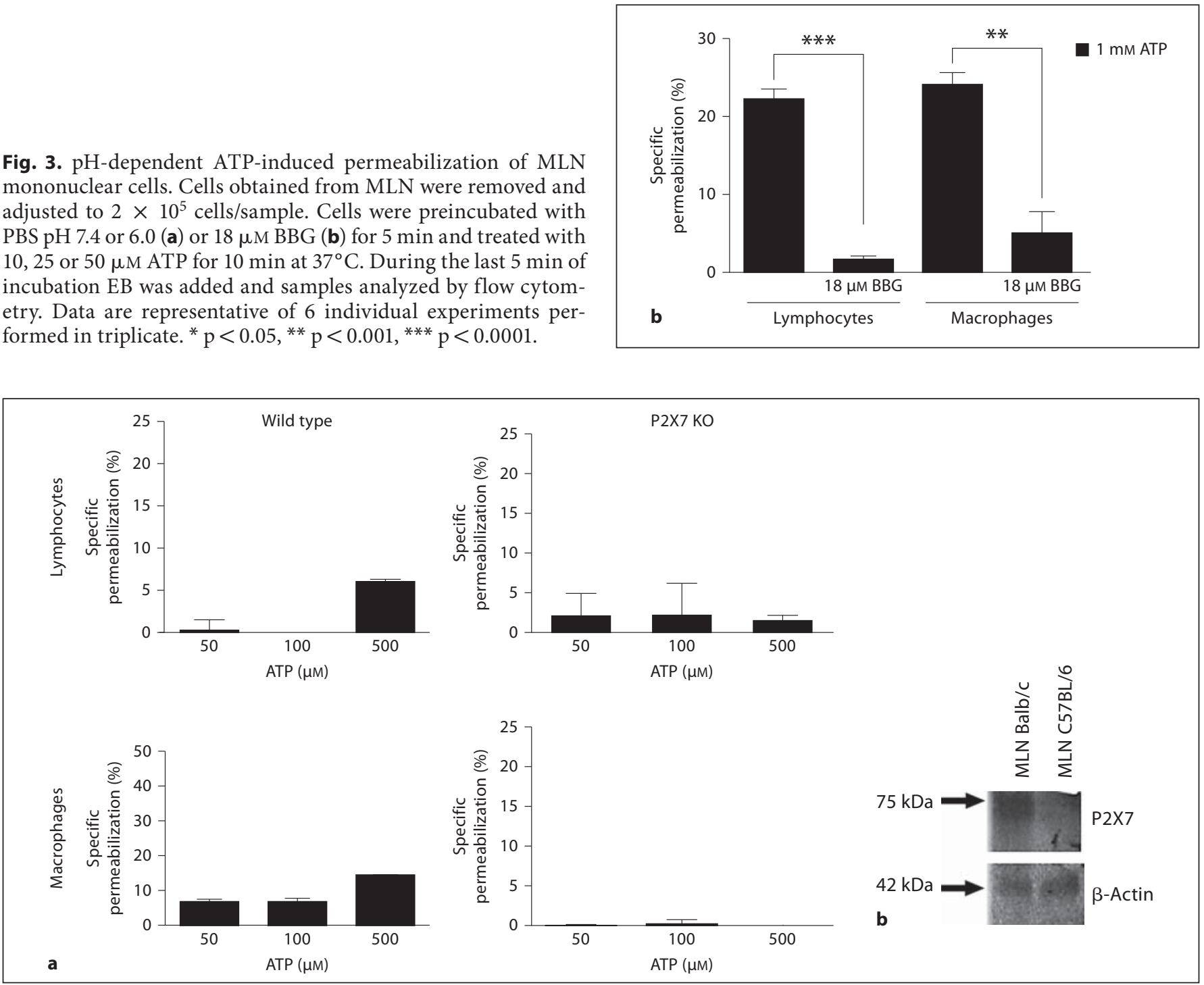

Fig. 4. $\mathrm{P} 2 \mathrm{X} 7^{-/-}$mice reveal that ATP-induced permeabilization is mediated by the P2X7 receptor. Cells obtained from MLN of C57BL/6 wild-type or $\mathrm{P} 2 \mathrm{X}^{-/-}$mice were removed and adjusted to $2 \times 10^{5}$ cells/sample. They were treated with 50,100 or $500 \mu \mathrm{M}$ ATP for $10 \mathrm{~min}$ at $37^{\circ} \mathrm{C}$. During the last 5 min of incubation EB was added and samples analyzed by flow cytometry. Data are a mean of 3 individual experiments performed in triplicate. ${ }^{* *} \mathrm{p}<$ $0.001,{ }^{* *} \mathrm{p}<0.0001$. a Mononuclear cells were removed from MLN of C57BL/6 or Balb/c mice and processed for Western blot analysis. Each lane contains $80 \mu \mathrm{g}$ of total protein sample. b Membranes incubated with polyclonal anti-P2X7 receptor antibody $(1: 1,000)$ or anti- $\beta$-actin antibody $(1: 2,000)$. 


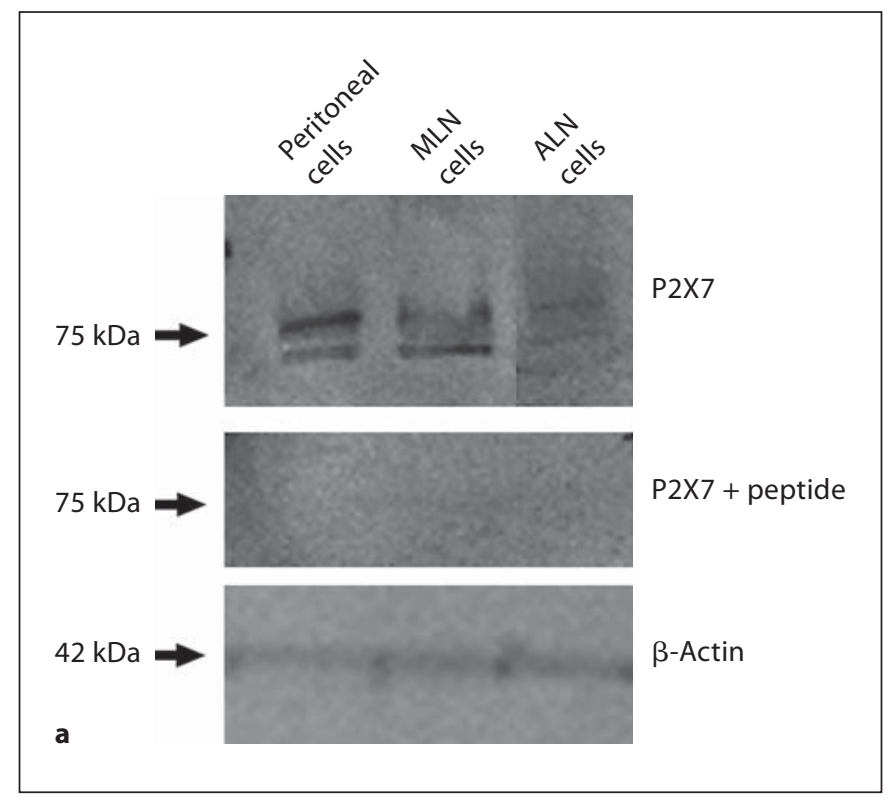

Fig. 5. P2X7 receptor is highly expressed in MLN. Cells obtained from peritoneal wash, MLN or ALN of Balb/c mice were isolated and protein extracted for Western blot analysis. Amount of protein loaded in each lane was $80 \mu \mathrm{g}$. a Membranes incubated with polyclonal anti-P2X7 receptor antibody $(1: 1,000)$, anti- $\beta$-actin

\section{Discussion}

The MLN are located in the gut and together with PP they comprise the gut-associated lymphoid tissue. The lymph nodes form a barrier that prevents the gut microbiota from reaching the systemic compartment of the host immune system where it could induce an inflammatory response. They also act as the sites for the generation and induction of the IgA antibodies that facilitate the destruction of commensal bacteria by the phagocytes of the intestinal mucosa [22]. The nucleotide receptors on the cell surface are called the $\mathrm{P} 2$ receptors and mediate the actions of the ATPe that is released mainly from damaged or inflamed tissues [1]. The $\mathrm{P} 2 \mathrm{X} 3$ receptor was detected in extracts from human intestines and is positively modulated in inflammation [23]. The increase in the expression of the $\mathrm{P} 2 \mathrm{X} 3$ receptor in the inflamed intestine suggests a potential role for this ion channel in the loss of motility and the pain associated with the inflammation, and this receptor may represent a new therapeutic target. The P2Y6 receptor is expressed in the infiltrating T cells in patients with inflammatory bowel disease but is absent in the T cells of healthy patients [24]. This study is one of the first to investigate the expression of a $\mathrm{P} 2$ receptor in dis-

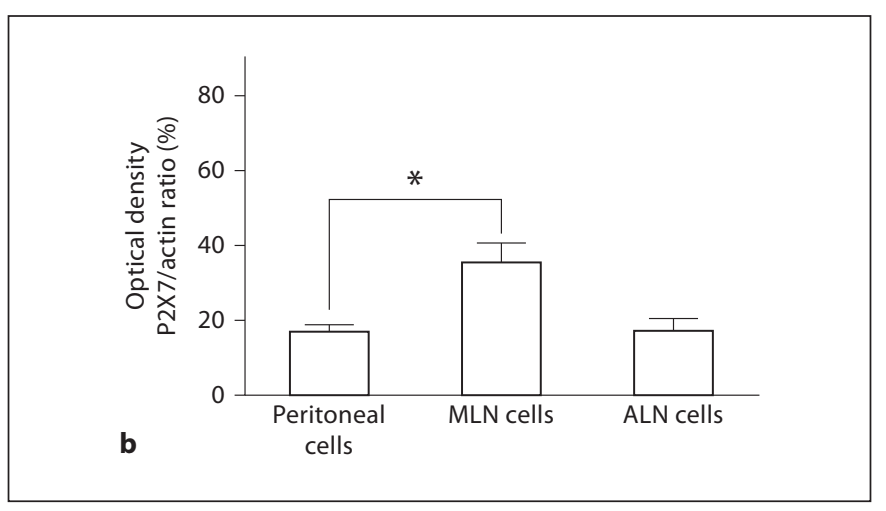

antibody $(1: 2,000)$ or control peptide (peritoneal, MLN and ALN cells). Blots are representative of 2 individual experiments. b Relative protein quantification was carried out using optical densitometric analysis of the bands. Data are representative of 2 individual experiments. ${ }^{*} \mathrm{p}<0.05$.

eased tissues, and the expression of the P2Y6 receptor and possibly other receptor subtypes may play a role in the pathogenesis of inflammatory bowel disease. The P2X7 and $\mathrm{P} 2 \mathrm{X} 5$ receptors are also expressed in the intestinal epithelium, and their expression has been associated with cell differentiation and cell death [14]. Therefore, we investigated the presence of the $\mathrm{P} 2$ receptors on mononuclear cells isolated from lymph nodes. The permeabilization of the cells by ATP showed that the mononuclear cells from the lymph nodes are more sensitive to ATPe than the mononuclear cells from other sites such as the peritoneum and spleen. The lymph nodes are in an environment that is constantly stimulated by commensal bacteria and pathogens. Their mononuclear cells, therefore, appear to be more sensitive to ATPe when compared to cells from other sites. In addition to the P2X7 receptors, other receptors were associated with pore formation. Due to the fact that ATP couples to all $\mathrm{P} 2 \mathrm{X}$ receptors, it is possible that the permeabilization phenomenon was associated with $\mathrm{P} 2 \mathrm{X}$ receptors other than the $\mathrm{P} 2 \mathrm{X} 7$ receptors that have been reported to allow the passage of dye molecules such as P2X2 and P2X4 [25]. Cells expressing the human P2X5 receptor quickly accumulate the dye $\mathrm{YO}-\mathrm{PRO}-1$ in response to ATP [26]. The $\mathrm{P} 2 \mathrm{X} 4, \mathrm{P} 2 \mathrm{X} 2$ and $\mathrm{P} 2 \mathrm{X} 2 / \mathrm{P} 2 \mathrm{X} 3$ re- 

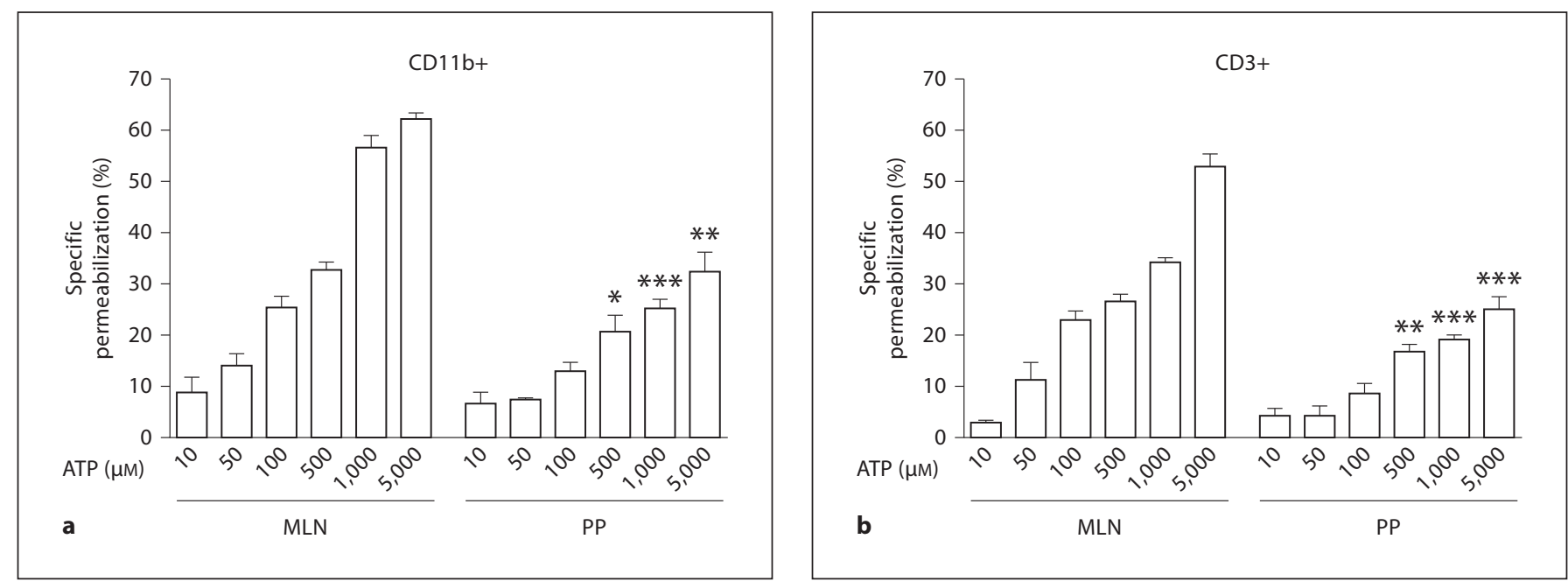

Fig. 6. Cells from PP are less sensitive to ATP than MLN cells. Cells from PP and MLN were isolated and adjusted to $2 \times 10^{5}$ cells/sample, stained with Mac-1(CD11b) (a) or CD3 (b) antibodies, processed for permeabilization assay and incubated with crescent concentrations of ATP for $10 \mathrm{~min}$ at $37^{\circ} \mathrm{C}$. During the last 5 min of incubation $\mathrm{EB}$ was added and samples analyzed by flow cytometry. Macrophages and lymphocytes were selected based on antibody staining. c Confocal microscopy of cytospin preparations showing relative distribution and levels of P2X7 receptor (red) and CD11b (green) in mononuclear cells freshly isolated from MLN, peritoneum and PP. Analysis of protein staining showed $\mathrm{P} 2 \mathrm{X} 7$ receptor densities are greater in MLN than in peritoneal or PP cells and a number of cells do not colocalize with CD11b. This observation may explain why the MLN cells, particularly the lymphocytes, are more sensitive to ATP permeabilization. Nuclei stained with DAPI (blue). Representative of 3 samples from each site. Scale bars represent $20 \mu \mathrm{m}$. Data are representative of 3 experiments. ${ }^{*} \mathrm{p}<0.05,{ }^{* *} \mathrm{p}<0.001,{ }^{* * *} \mathrm{p}<0.0001$.

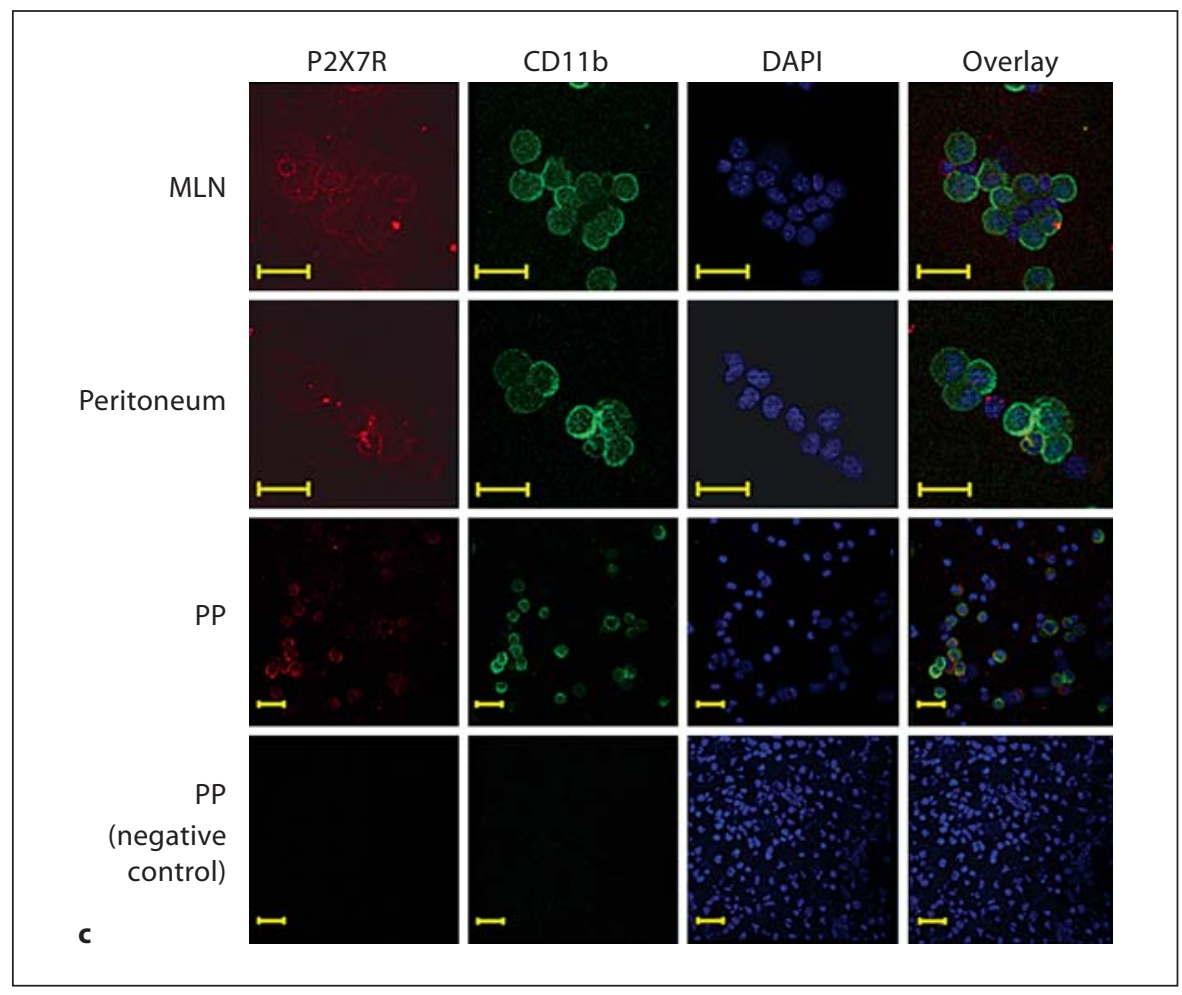

ceptors also appear to have an increased pore diameter depending on the ATP exposure time [27]. The macrophages and lymphocytes from the lymph nodes are more susceptible to ATPe compared with the macrophages and lymphocytes from other sources. The literature reports that the $\mathrm{EC}_{50}$ for the agonist (ATP) of the $\mathrm{P} 2 \mathrm{X} 7$ receptor is approximately $780 \mu \mathrm{M}$ in macrophages [28]. Several hypotheses could explain this increase in the sensitivity to ATPe. It has been suggested that there is a site-specific modulation of the expression and sensitivity of the P2X7 receptor due to the characteristics of the lymph nodes which are continuously responding to the bacterial products of the gut commensal microbiota thereby maintaining tolerance to them [29]. Another hypothesis, which is not exclusionary, is the presence of other $\mathrm{P} 2 \mathrm{X}$ receptors in the lymphocytes and macrophages in the lymph nodes. It has been demonstrated that the P2X7 receptor ion currents can be inhibited by the application of calcium, mag- 


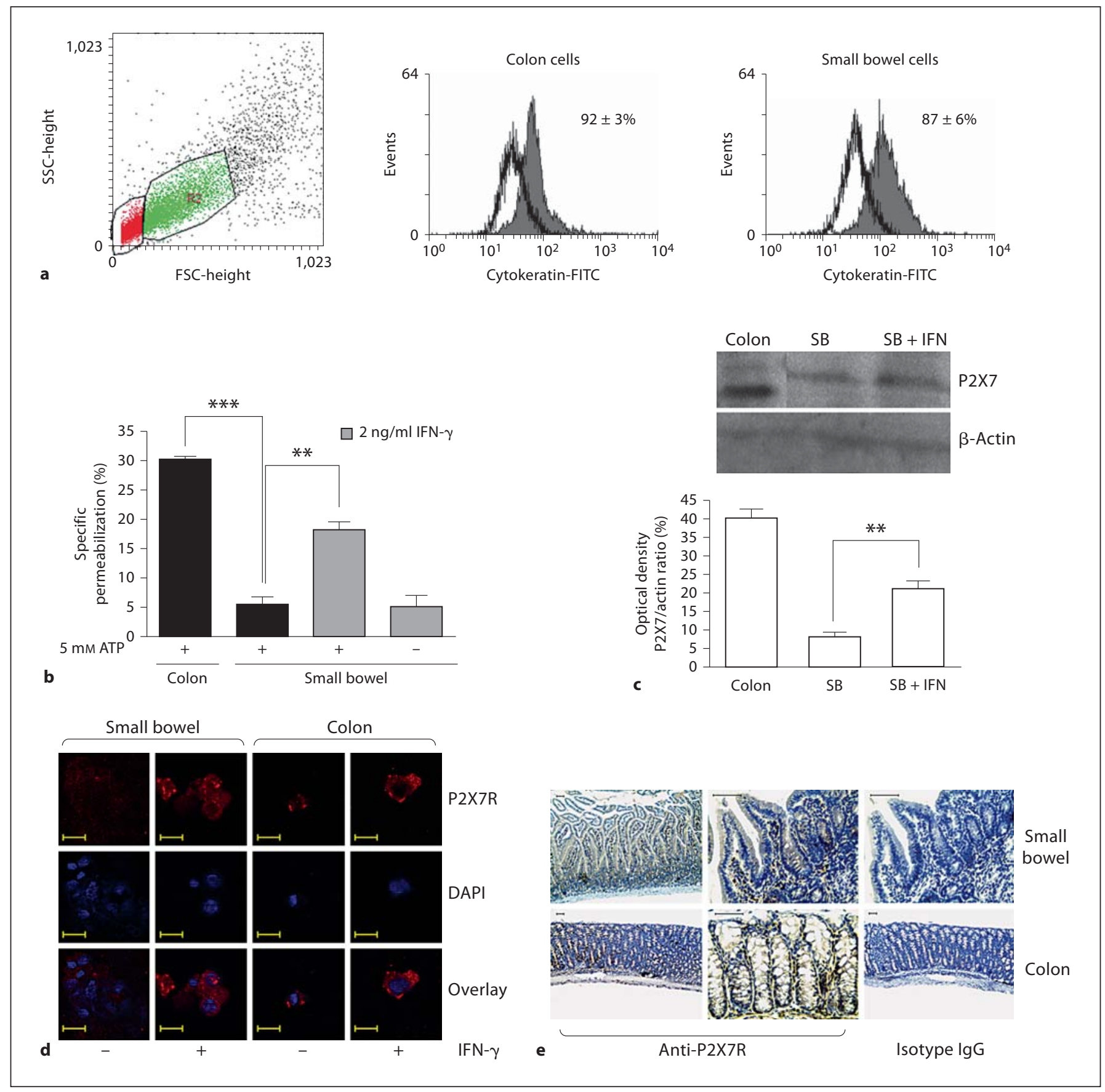

Fig. 7. Epithelial cells from the colon but not from the small bowel permeabilize following incubation with ATP. Colonic and small bowel epithelial cells were isolated and adjusted to $2 \times 10^{5}$ cells/sample. Epithelial cells were preexposed to $2 \mathrm{ng} / \mathrm{ml} \mathrm{IFN- \gamma}$ for $24 \mathrm{~h}$, incubated with $5 \mathrm{mM} \mathrm{ATP}$ for $10 \mathrm{~min}$ at $37^{\circ} \mathrm{C}$ (b) or processed for Western blot analysis (c) and confocal microscopy (d). During the last $5 \mathrm{~min}$ of incubation EB was added and samples analyzed by flow cytometry. ${ }^{* *} \mathrm{p}<0.001,{ }^{* * *} \mathrm{p}<0.0001(\mathbf{a}, \mathbf{b})$. a Epithelial cells were selected on dot plot gate R2 and cytokera-
tin-FITC staining. d Confocal microscopy of cytospin preparations showing the relative distribution and levels of $\mathrm{P} 2 \mathrm{X} 7$ receptor (red) in freshly isolated epithelial cells from the small bowel and colon. Nuclei stained with DAPI (blue). Representative of 3 experiments from each site. Scale bars represent $20 \mu \mathrm{m}$. e P2X7 receptor immunostaining (brown) is shown in the small bowel and colon of normal mice. Representative of 6 independent samples. Scale bars represent $50 \mu \mathrm{m}$. SB = Small bowel. 


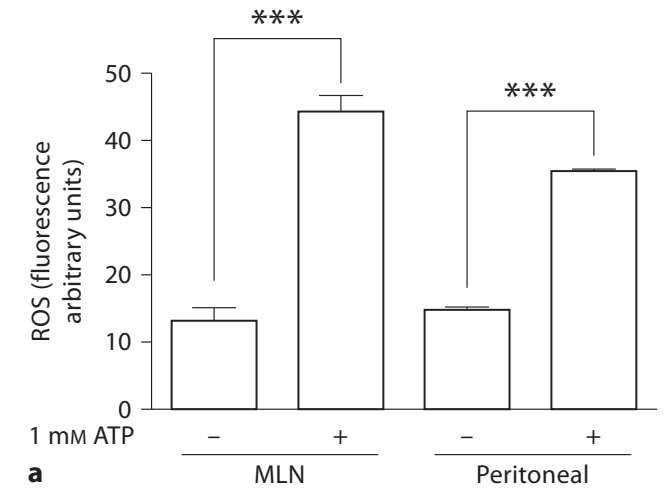

Fig. 8. MLN and peritoneal cells produce ROS and IL-1 $\beta$ induced by the ATP. MLN and cells obtained from peritoneal wash were incubated with $\mathrm{H}_{2}$ DCFDA for $30 \mathrm{~min}$ at $37^{\circ} \mathrm{C}$, washed and incubated for $15 \mathrm{~min}$ with $1 \mathrm{mM}$ ATP. ATP-induced ROS production from Balb/c (a) and C57BL/6 WT and C57BL/6 P2X7 ${ }^{-/-}$(b) mice was analyzed by flow cytometry. Cells from $\mathrm{BALB} / \mathrm{c}$ mice were incubated or not incubated with $10 \mathrm{ng} / \mathrm{ml} \mathrm{LPS}$ for $4 \mathrm{~h}$ at $37^{\circ} \mathrm{C}$ followed by incubation with $1 \mathrm{mM}$ ATP for an additional $3 \mathrm{~h}$. Supernatants were collected and analyzed for IL-1 $\beta$ release $(\mathbf{c})$. WT $=$ Wild type. ${ }^{*} \mathrm{p}<0.05,{ }^{* *} \mathrm{p}<0.001,{ }^{* *} \mathrm{p}<0.0001$.

nesium, zinc, copper and protons in the extracellular halves of their maximal inhibitory concentrations $\left(\mathrm{IC}_{50}\right)$. These results show that the divalent cations and protons act primarily as allosteric modulators to alter the affinity of ATP binding to the P2X7 receptor [30]. Based on these data we investigated the first hypothesis. With the preapplication of copper, zinc and cadmium, the permeabilization of the plasma membrane of the mononuclear cells was inhibited. These cations are known to inhibit the $\mathrm{P} 2 \mathrm{X} 7$ receptor. The function of other $\mathrm{P} 2 \mathrm{X}$ receptors is also modified by the addition of divalent cations. Zinc potentiates the $\mathrm{P} 2 \mathrm{X} 2$ and $\mathrm{P} 2 \mathrm{X} 4$ receptor currents, and copper potentiates the $\mathrm{P} 2 \mathrm{X} 2$ receptor and inhibits the $\mathrm{P} 2 \mathrm{X} 4$ receptor [1]. Our data showed that with the addition of the copper, cadmium and zinc cations, the permeabilization of the mononuclear cells was inhibited and, therefore, it
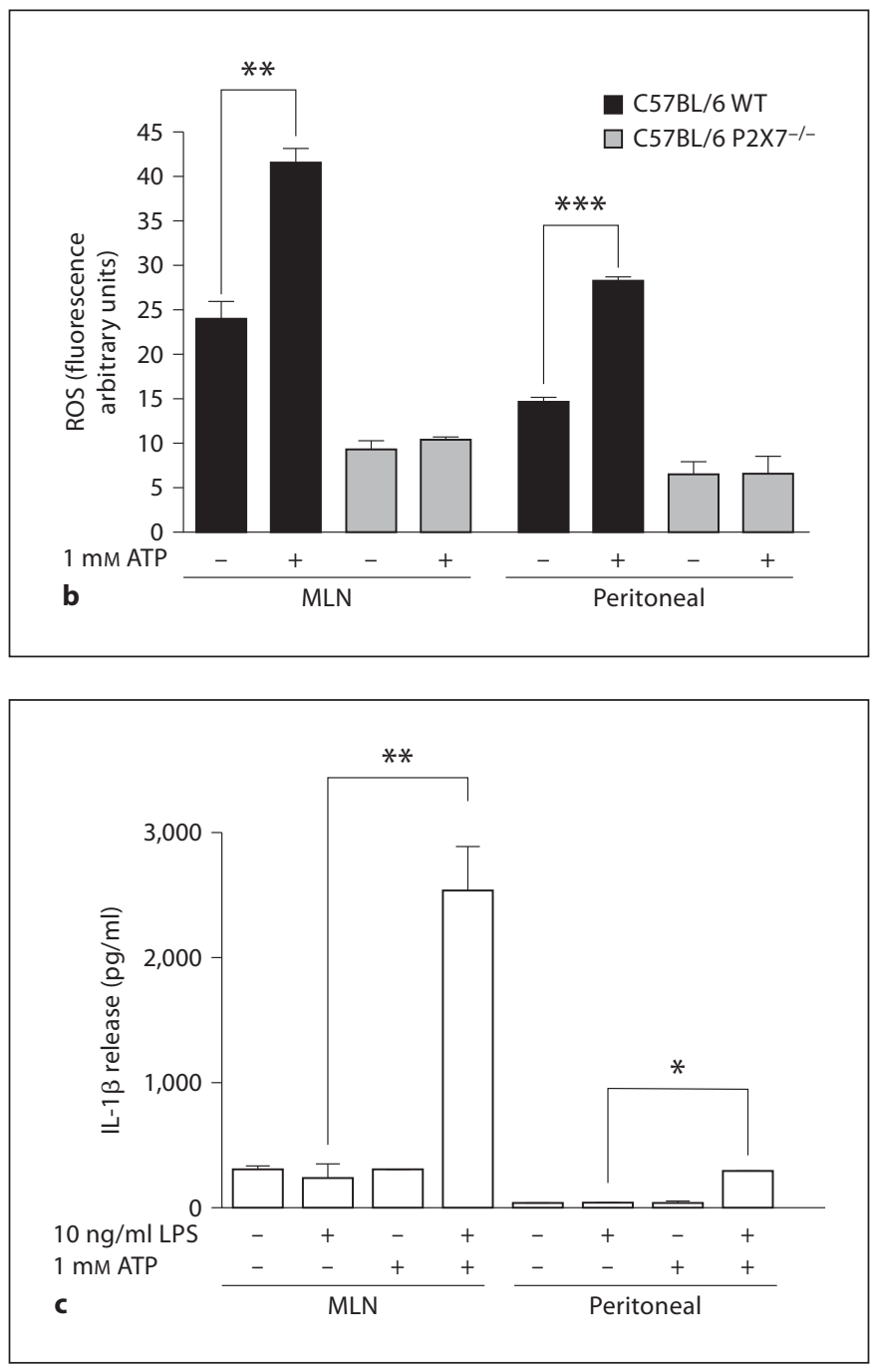

appears that the $\mathrm{P} 2 \mathrm{X} 2$ and $\mathrm{P} 2 \mathrm{X} 4$ receptors are not working. In addition, we used a more specific blocker of the P2X7 receptor, BBG, and once again observed a reduction in the membrane permeabilization of the cells at different concentrations. This inhibition in the lymphocytes from the lymph nodes was almost complete at nanomolar concentrations, which is ideal for the $\mathrm{P} 2 \mathrm{X} 7$ receptor as described by North [1]. Finally, we performed the same test in the P2X7 receptor knockout animals and noted that there was no permeabilization of the mononuclear cells. Thus, we conclude that the observed effect on the mononuclear cells from the lymph nodes is due to the activation of the $\mathrm{P} 2 \mathrm{X} 7$ receptor. This is one of the first studies to report the activation of the $\mathrm{P} 2 \mathrm{X} 7$ receptors by ATP in micromolar concentrations which are closer to physiological concentrations. 
The P2X7 receptor stimulation by ATPe results in numerous effects including the activation of caspase-1, the breach of pro-IL-1 $\beta$ secretion and IL- $1 \beta$ maturation [31], and the elimination of intracellular pathogens $[5,18,19$, $32-34]$. The $\mathrm{P} 2 \mathrm{X} 7$ receptor is positively regulated in macrophages by inflammatory cytokines such as IFN- $\gamma[9-$ 11] and TNF- $\alpha$ and by LPS [12]. Studies with mice that are deficient in the $\mathrm{P} 2 \mathrm{X} 7$ receptor showed that the $\mathrm{P} 2 \mathrm{X} 7$ receptors are involved in inflammation [19]. The disruption of the P2X7 gene is associated with a less severe disease in a model of arthritis [35] and in studies of chronic inflammation and neuropathic pain [36]. The P2X7 receptor is present and its expression is modulated by inflammation in chronic inflammation sites. The P2X7 receptor-dependent signaling plays a significant role in the host response during various inflammatory diseases [37]. Cesaro et al. [38] demonstrated the importance of P2X7 activation during the intestinal inflammatory process showing that the activation of the epithelial P2X7 receptor is crucial for the PMNL-induced caspase- 1 activation and IL-1 $\beta$ release by the intestinal epithelial cells.

Understanding the signaling nucleotides involved in the immune response is of the utmost importance for the development of new treatment guidelines for combating infectious diseases. Sensory nerves in the gastrointestinal tract express P2X receptors and the ATP released from the gastrointestinal cells activates these receptors and motor reflexes and transmits nociceptive stimuli [39]. In addition, the nucleotides and nucleotide receptors are thought to be involved in the pathogenesis of inflammatory bowel disease. For example, antagonists of the P2X receptors in sensory nerves were shown to attenuate abdominal pain in patients with inflammatory bowel disease [39]. Furthermore, in a model of inflammatory bowel disease in rats, the presence of nucleotides in the diet increases the number of damaged intestinal epithelial cells [40]. Hence, it is crucial to obtain more information about the presence, distribution and function of the P2X receptors in the intestinal immune cells and epithelial cells, and this information will potentially generate new avenues for the treatment of patients with inflammatory bowel disease.

In this study, we observed that cells from the small bowel were permeabilized to a lesser extent than cells from the colon. We hypothesize that this is due to the differences in the numbers and composition of the intestinal microbiota and the different physiological functions of the colon and the small bowel. In view of the greater challenge of differentiating the pathogenic from the nonpathogenic stimuli in the colon, it would be reasonable to

examine additional protective mechanisms, which include the ATP-activated P2X7 receptors, as an additional component of the innate immune circuits that control intestinal homeostasis [41]. In fact, there appears to be an increased need to elicit an inflammatory response and to induce cell apoptosis in the colon. This theory is supported by the demonstration of the increasing permeabilization of small bowel enterocytes following pretreatment with IFN- $\gamma$, a proinflammatory cytokine and a signature molecule of the Th-1 type of immune response.

In conclusion, our findings suggest the site-specific modulation of the P2X7 receptors on epithelial and immune cells and define purinergic signaling as a novel regulatory element in the control of inflammation and cell fate in the gut and the gut-associated lymphoid tissues. The epithelial $\mathrm{P} 2 \mathrm{X} 7$ receptor upregulation in response to IFN- $\gamma$ is consistent with the involvement of purinoceptors in ATP-induced apoptotic cell death. Taken together, these observations implicate P2X7 in the pathogenesis of diseases based on the dysregulation of the immune response such as inflammatory bowel disease.

\section{Acknowledgements}

We are grateful to Mrs. Pryscilla Braga and Vandir Costa for their technical assistance. This work was supported by funds from the Conselho Nacional de Desenvolvimento Cientifico e Tecnológico do Brasil (CNPq), the Programa de Núcleos de Excelência (PRONEX), Fundação de Amparo à Pesquisa do Estado do Rio de Janeiro (FAPERJ) and the Instituto Nacional de Ciência e Tecnologia para Pesquisa Translacional em Saúde e Ambiente na Região Amazônica (INPeTAm/UFRJ).

References

J Innate Immun 2012;4:529-541
1 North RA: Molecular physiology of P2X receptors. Physiol Rev 2002;82:1013-1067.

$\checkmark 2$ Chen L, Brosnan CF: Regulation of immune response by P2X7 receptor. Crit Rev Immunol 2006;26:499-513.

-3 Qu Y, Ramachandra L, Mohr S, Franchi L, Harding CV, Nunez G, Dubyak GR: P2X7 receptor-stimulated secretion of $\mathrm{MHC}$ class II-containing exosomes requires the ASC/ NLRP3 inflammasome but is independent of caspase-1. J Immunol 2009;182:5052-5062.

4 Lopez-Castejon G, Theaker J, Pelegrin P, Clifton AD, Braddock M, Surprenant A: $\mathrm{P} 2 \mathrm{X}(7)$ receptor-mediated release of cathepsins from macrophages is a cytokine-independent mechanism potentially involved in joint diseases. J Immunol 2010;185:26112619. 
5 Coutinho-Silva R, Correa G, Sater AA, Ojcius DM: The P2X(7) receptor and intracellular pathogens: a continuing struggle. Purinergic Signal 2009;5:197-204.

6 Abbracchio MP, Burnstock G: Purinergic signalling: pathophysiological roles. Jpn J Pharmacol 1998;78:113-145.

$\checkmark 7$ Haag F, Adriouch S, Brass A, Jung C, Moller S, Scheuplein F, Bannas P, Seman M, KochNolte F: Extracellular NAD and ATP: partners in immune cell modulation. Purinergic Signal 2007;3:71-81.

8 Hong S, Schwarz N, Brass A, Seman M, Haag F, Koch-Nolte F, Schilling WP, Dubyak GR: Differential regulation of $\mathrm{P} 2 \mathrm{X} 7$ receptor activation by extracellular nicotinamide adenine dinucleotide and ecto-ADP-ribosyltransferases in murine macrophages and $\mathrm{T}$ cells. J Immunol 2009;183:578-592.

-9 Welter-Stahl L, da Silva CM, Schachter J, Persechini PM, Souza HS, Ojcius DM, Coutinho-Silva R: Expression of purinergic receptors and modulation of $\mathrm{P} 2 \mathrm{X} 7$ function by the inflammatory cytokine IFNgamma in human epithelial cells. Biochim Biophys Acta 2009;1788:1176-1187.

10 Blanchard DK, McMillen S, Djeu JY: IFNgamma enhances sensitivity of human macrophages to extracellular ATP-mediated lysis. J Immunol 1991;147:2579-2585.

- 11 Hickman SE, el Khoury J, Greenberg S, Schieren I, Silverstein SC: P2Z adenosine triphosphate receptor activity in cultured human monocyte-derived macrophages. Blood 1994;84:2452-2456.

-12 Humphreys BD, Dubyak GR: Modulation of P2X7 nucleotide receptor expression by proand anti-inflammatory stimuli in THP-1 monocytes. J Leukoc Biol 1998;64:265-273.

$\checkmark 13$ Ito M, Matsuoka I: Regulation of purinergic signaling by prostaglandin E2 in murine macrophages. J Pharmacol Sci 2008; 107: 443-450.

-14 Groschel-Stewart U, Bardini M, Robson T, Burnstock G: P2X receptors in the rat duodenal villus. Cell Tissue Res 1999;297:111-117.

$\longrightarrow 15$ Miki K, Tanaka H, Nagai Y, Kimura C, Oike $\mathrm{M}$ : Transforming growth factor betal alters calcium mobilizing properties and endogenous ATP release in A549 cells: possible implications for cell migration. J Pharmacol Sci 2010;113:387-394.

16 Ramsingh R, Grygorczyk A, Solecki A, Cherkaoui LS, Berthiaume Y, Grygorczyk R: Cell deformation at the air-liquid interface induces $\mathrm{Ca}^{2+}$-dependent ATP release from lung epithelial cells. Am J Physiol Lung Cell Mol Physiol 2011;300:L587-L595.

17 Dezaki K, Tsumura T, Maeno E, Okada Y: Receptor-mediated facilitation of cell volume regulation by swelling-induced ATP release in human epithelial cells. Jpn J Physiol 2000;50:235-241.
Coutinho-Silva R, Perfettini JL, Persechini PM, Dautry-Varsat A, Ojcius DM: Modulation of $\mathrm{P} 2 \mathrm{Z} / \mathrm{P} 2 \mathrm{X}(7)$ receptor activity in macrophages infected with Chlamydia psittaci. Am J Physiol Cell Physiol 2001;280:C81C89.

19 Coutinho-Silva R, Stahl L, Raymond MN, Jungas T, Verbeke P, Burnstock G, Darville T, Ojcius DM: Inhibition of chlamydial infectious activity due to P2X7R-dependent phospholipase D activation. Immunity 2003; 19:403-412.

20 Nihei OK, Savino W, Alves LA: Procedures to characterize and study $\mathrm{P} 2 \mathrm{Z} / \mathrm{P} 2 \mathrm{X} 7$ purinoceptor: flow cytometry as a promising practical, reliable tool. Mem Inst Oswaldo Cruz 2000;95:415-428.

21 Korpi-Steiner NL, Sheerar D, Puffer EB, Urben C, Boyd J, Guadarrama A, Schell K, Denlinger LC: Standardized method to minimize variability in a functional P2X(7) flow cytometric assay for a multi-center clinical trial. Cytometry B Clin Cytom 2008;74:319329.

22 Macpherson AJ, Uhr T: Compartmentalization of the mucosal immune responses to commensal intestinal bacteria. Ann NY Acad Sci 2004;1029:36-43.

23 Yiangou Y, Facer P, Baecker PA, Ford AP, Knowles CH, Chan CL, Williams NS, Anand $\mathrm{P}$ : ATP-gated ion channel P2X(3) is increased in human inflammatory bowel disease. Neurogastroenterol Motil 2001;13:365-369.

24 Somers GR, Hammet FM, Trute L, Southey MC, Venter DJ: Expression of the P2Y6 purinergic receptor in human $\mathrm{T}$ cells infiltrating inflammatory bowel disease. Lab Invest 1998;78:1375-1383.

-25 Marques-da-Silva C, Chaves MM, Castro NG, Coutinho-Silva R, Guimaraes MZ: Colchicine inhibits cationic dye uptake induced by ATP in P2X2 and P2X7 receptor-expressing cells: implications for its therapeutic action. Br J Pharmacol 2011;163:912-926.

26 Bo X, Jiang LH, Wilson HL, Kim M, Burnstock G, Surprenant A, North RA: Pharmacological and biophysical properties of the human P2X5 receptor. Mol Pharmacol 2003; 63:1407-1416.

27 Khakh BS, Bao XR, Labarca C, Lester HA: Neuronal P2X transmitter-gated cation channels change their ion selectivity in seconds. Nat Neurosci 1999;2:322-330.

28 Jacobson KA, Kim YC, King BF: In search of selective $\mathrm{P} 2$ receptor ligands: interaction of dihydropyridine derivatives at recombinant rat P2X(2) receptors. J Auton Nerv Syst 2000; 81:152-157.

29 Hooper LV, Gordon JI: Commensal hostbacterial relationships in the gut. Science 2001;292:1115-1118.

30 Virginio C, MacKenzie A, North RA, Surprenant A: Kinetics of cell lysis, dye uptake and permeability changes in cells expressing the rat P2X7 receptor. J Physiol 1999;519: 335-346.
31 MacKenzie A, Wilson HL, Kiss-Toth E, Dower SK, North RA, Surprenant A: Rapid secretion of interleukin-1beta by microvesicle shedding. Immunity 2001;15:825-835.

- 32 Fairbairn IP, Stober CB, Kumararatne DS, Lammas DA: ATP-mediated killing of intracellular mycobacteria by macrophages is a P2X(7)-dependent process inducing bacterial death by phagosome-lysosome fusion. J Immunol 2001;167:3300-3307.

33 Kusner DJ, Barton JA: ATP stimulates human macrophages to kill intracellular virulent Mycobacterium tuberculosis via calcium-dependent phagosome-lysosome fusion. J Immunol 2001;167:3308-3315.

-34 Correa G, Marques da SC, de Abreu MoreiraSouza AC, Vommaro RC, Coutinho-Silva R: Activation of the $\mathrm{P} 2 \mathrm{X}(7)$ receptor triggers the elimination of Toxoplasma gondii tachyzoites from infected macrophages. Microbes Infect 2010;12:497-504.

35 Labasi JM, Petrushova N, Donovan C, McCurdy S, Lira P, Payette MM, Brissette W, Wicks JR, Audoly L, Gabel CA: Absence of the $\mathrm{P} 2 \mathrm{X} 7$ receptor alters leukocyte function and attenuates an inflammatory response. J Immunol 2002;168:6436-6445.

- 36 Chessell IP, Hatcher JP, Bountra C, Michel AD, Hughes JP, Green P, Egerton J, Murfin M, Richardson J, Peck WL, Grahames CB, Casula MA, Yiangou Y, Birch R, Anand P, Buell GN: Disruption of the P2X7 purinoceptor gene abolishes chronic inflammatory and neuropathic pain. Pain 2005;114:386-396.

37 Goncalves RG, Gabrich L, Rosario A Jr, Takiya CM, Ferreira ML, Chiarini LB, Persechini PM, Coutinho-Silva R, Leite M Jr: The role of purinergic $\mathrm{P} 2 \mathrm{X} 7$ receptors in the inflammation and fibrosis of unilateral ureteral obstruction in mice. Kidney Int 2006; 70:1599-1606.

38 Cesaro A, Brest P, Hofman V, Hebuterne X, Wildman S, Ferrua B, Marchetti S, Doglio A, Vouret-Craviari V, Galland F, Naquet P, Mograbi B, Unwin R, Hofman P: Amplification loop of the inflammatory process is induced by P2X7R activation in intestinal epithelial cells in response to neutrophil transepithelial migration. Am J Physiol Gastrointest Liver Physiol 2010;299:G32-G42.

39 Galligan JJ: Enteric P2X receptors as potential targets for drug treatment of the irritable bowel syndrome. Br J Pharmacol 2004;141: 1294-1302.

40 Adjei AA, Ameho CK, Harrison EK, Yamauchi K, Kulkarni A, Kawajiri A, Yamamoto S: Nucleoside-nucleotide-free diet suppresses cytokine production and contact sensitivity responses in rats with trinitrobenzene sulphonic acid-induced colitis. Am J Med Sci 1997;314:89-96.

41 Harrison OJ, Maloy KJ: Innate immune activation in intestinal homeostasis. J Innate Immun 2011;3:585-593. 